\title{
Measurement and Improvement of the happiness. Case Study: Engineering Projects Employees
}

\section{Medición y mejoramiento de la felicidad. Estudio de Caso: Empleados de Proyectos de Ingeniería}

DOI: https://doi.org/10.17981/ijmsor.04.01.01

Research Article - Reception Date: Feb 4, 2019-Acceptance Date: Apr 17, 2019

\section{Lady Mariana Arroyo-Moya, Cesar Danilo Santiago Duque,} Blass Troncoso-Mendoza and Alexander Troncoso-Palacio Productivity and Innovation Department, Universidad de la Costa. Barranquilla (Colombia). larroyo3@cuc.edu.co, csantiag1@cuc.edu.co, btroncos@cuc.edu.co, atroncos1@cuc.edu.co

To reference this paper:

L. Arroyo Moya, C. Santiago Duque, B. Troncoso Mendoza, \& A. Troncoso Palacio "Measurement and Improvement of the happiness. Case Study: Engineering Projects Employees", IJMSOR, vol. 4, no. 1, 2019. https://doi. org/10.17981/ijmsor.04.01.01

Abstract - The construction of civil works is the development index of a nation, in countries like Colombia, this sector depends on the human factor, which is why it is of utmost importance that employees are happy in carrying out their daily activities. Due to this, this study was developed to measure the degree of job satisfaction on a scale of five response levels in a civil works construction company, where the concepts of the vertical workload theory were applied, through the which, they indicated their degree of satisfaction. The results obtained reveal that, at the beginning of each workday, the boss should hold meetings with the intention of motivating. In addition, he should carry out group recreational activities or active breaks so that the work environment improves continuously and a better performance of the workers, which will allow a high probability of increasing the company's productivity.

KeyWords--Civil Works Construction; Engineering Projects; Happiness Employees; job Contentment; Job Satisfaction; Vertical Job Loading.
Resumen - La construcción de obras civiles es el índice de desarrollo de una nación, en países como Colombia, este sector depende del factor humano, por lo cual es de suma importancia que, los empleados estén felices en la realización de sus actividades diarias. Debido a ello, se desarrolló este estudio para medir el grado de satisfacción laboral en una escala de cinco niveles de respuesta en una compañía de construcción de obras civiles, donde se aplicaron los conceptos de la teoría de carga vertical de trabajo, a través de los cuales, ellos indicaban su grado de satisfacción. Los resultados obtenidos revelan que, al inicio de cada jornada laboral, el jefe debería realizar reuniones con la intención de motivar, Además, debería realizar actividades recreativas grupales o pausas activas para que el ambiente de trabajo mejore continuamente y se obtenga un mejor desempeño de los trabajadores, lo que permitirá una alta probabilidad de aumentar la productividad de la compañía.

Palabras clave - Carga de trabajo vertical; Construcción de obras civiles; Empleados felices; Proyectos de ingeniería; Satisfacción laboral.

\footnotetext{
The author; licensee Fundación para la Investigación, el Desarrollo y la Innovación I+D+I 


\section{INTRODUCTION}

The world economy driven by the contribution provided by the business sector, in which the creation occurs jobs that lead to the reduction of poverty, in accordance with [1]. Despite the fact that there is currently an economic crisis, this does not affect the fact that every day money invested in engineering projects, constantly generating opportunities for many people. The human resource it is the most important factor in the growth of this sector, it is the one that assumes a large part of the costs of most of the projects, because this industry employs a wide variety of people with different training and occupational culture, including workers without qualification, skilled workers, professionals, executive and administrative positions. This group of workers as varied operates as an itinerant labor, working in teams to meet objectives in short, average and long term within a project, in a variety of locations. Therefore, the structure of the projects industry consists of many disparate organizations that join with the intention of achieving so many goals shared projects, such as individual organizational objectives. In addition, these objectives are not necessarily compatible and cannot aligned with the personal objectives of the employees.

As mentioned above, it can see the important role people play within a company or human resources project. Therefore, it is necessary to design motivation strategies that allow employees to stay focused on the vision, and not only on remuneration, bonuses and intrinsic factors, so they can achieve satisfaction in development their activities. Nevertheless, there are other fundamental aspects, when the worker wants to grow personally in any area, where people become pillars of growth for the Organization. Someone defined the motivation as a generic term applied to a series of impulses, desires, needs, aspirations and the like. In the field of work, reason would be the inner strength that pushes people to work and care for their task, is an internal state that activates or leads to something; it is what energizes, directs, and maintains the actions and behavior of employees [2]. In the case of employee Robert H. Warren, defines it as "the combination of influences that makes workers want to do a job as soon as possible in accordance with the objectives of safety and quality while collaborates with fellow at the execution of a" project as a whole" [3]. In Colombia in many sectors of the industry, they have used different theories, which seek to motivate their employees in order to achieve higher productivity, obtaining positive results; however, the study of these has been minimal. In [4] an investigation in the small and medium-sized companies of the textile sector in Barranquilla determined that employee satisfaction rates are below the world average. Also [5] concluded that the global effects in this sector require the definition of strategies made by Colombian companies, aimed at enhancing job satisfaction, considering human resource as the most important factor in competitiveness. In Colombia, according to [6], the investment in civil works indicator is it used to calculate the gross domestic product of the country. Due to the above exposed, it is important to evaluate the theory of application of the vertical load created by psychologist Frederick Herzberg, so that a system can be implemented to encourage workers to direct labor without compensation if necessary economic additional, or work extra hours, which is one of largest incidents of losses in the execution of a project

\section{RESEARCH OF LITERATURE}

Is extremely important that the Department of human resources within organizations assess the general behavior of the workers and the role that each one represents the business objectives, in this way it be have highly competitive enterprises with quality staff. In general terms at the dawn of the new millennium, it seems to be consensus in that the study of labor motivation is in a critical phase due mainly to lack of renewal and the limitations of the traditional theories [7]. When Frederick Herzberg investigated the sources of motivation of employees during the 1950s and 1960s, he discovered a dichotomy that still today intrigues and bewilders to managers: The things that motivate and satisfy people at work are different from those that cause dissatisfaction. [8], [9]. According to the PMBOK® Guide, Human Resources Management within a project includes the processes that organize, manage and conduct the project team. Although each member of the team must assigned his or her role and responsibilities, the participation of all the members is crucial, because with it we get them to contribute their professional experiences and in addition, strengthen its commitment with the Project [10], [11].

In the search for business competitiveness in the New Economy, the managers should have leadership styles and administrative practices of high efficiency and performance of human resources [12], but at present, there is a great lack of knowledge in companies due to the excessive use of extrinsic factors such as variable wages and salaries as motivational sources. [13], The importance of the study of the organizational climate in a company based on the verification of how this influences the manifest behavior of the collaborators, through stabilized perceptions that filter reality and condition the levels of job motivation and professional performance. [14]. It is because of that Motivation plays a key role in the workplace, it has the ability to achieve a high level of work spirit in employees, improve their performance and a sense of satisfaction in having a job, all this allows efficiency for your company [15]. This implies that decision makers must identify the needs of their workers and offer them the means to satisfy them. [16]. Therefore, the science of behavior focuses in the feelings of group, the attitudes of the individuals, the social climate and the psychological aspect of the organizations. Where theory suggests that to reach the effective use of personnel it should to motivate employees for enriched the companies, thus directly influencing the attitudes and behavior of staff. [17]. This is how its human resources determine the effectiveness and efficiency of a company because only through these is the effectiveness of other existing resources possible [18]. In this way, having job dissatisfaction as well as producing inefficiencies in the 
organizations, in most cases would generate aggressive behavior with all its implications. [19]. Therefore, in labor matters, the degree of motivation is important, since it directly affects the performance of the assigned activity and, consequently, in the operation of the company or organization in which it is linked. [20]. A satisfactory work environment, on the other hand, will allow the staff to maintain stable physical and mental conditions. The factors of psychosocial risk of work such as stress, workload, difficulties in socioprofessional relationships and inadequate work conditions, it can considered variables that interfere in the mental and physical health of the employees. [21].

Therefore, one of the objectives of management is to get the best from employees, the quality of the individual relationships that each of the workers has with their managers, the trust, respect and consideration that the bosses provide daily to their employees. Subalterns is a product of the "motivation" aspect of management. [22]. The people, both in their work and private lives, act according to their behavior patterns, which explained through changes in their environment and work environment. [23]. Likewise, the Labor Social Welfare refers to the state of satisfaction achieved by the employee in the exercise of his functions, product of a pleasant work environment and the recognition of his work. The concept of quality of life, linked to the health and wellbeing of the individual, is separated from the definition of work welfare, to the extent that it favors their subsistence conditions and also as a dynamic concept, definable in terms of its effects, not only physical and biological, but ethical and social. Its quality measured by the degree of security enjoyed by the human being, but at the same time by the degree of satisfaction perceived. [24] Nowadays, the Quality of Work Life is one of the concepts that has generated the greatest interest in companies that seek to differentiate themselves from their competitors and impose themselves in the market, taking an interest in and taking care of their human beings. Capital, which is the main thing in any organization. [25]. This is how Loyalty to the human capital of organizations has thus become the main mission of entrepreneurs. [26]. The challenge for managers is to demonstrate their leadership skills, designing a pleasant organizational climate, so that all workers feel comfortable in the organization, responsibly perform their functions, where their coexistence relationships allow them to interact with others in an opportunity for dialogue, with acceptance of differences, consensus building and acceptance of disagreements. [27]. According to Frederick Herzberg's Bi-factor theory, it can differentiate: The hygienic factors are those related to the environment that surrounds people and cover the conditions in which they perform their work. The variables that are managed by the company, such as relations with the boss, relations with co-workers, prestige or status, good working conditions, Policies and Guidelines for Organization and Safety at work. The motivational factors, more directly related to the satisfaction of the person, such as the Work itself as a positive stimulus, professional recognition, Professional Development, Responsibility, Opportunity for Growth and personal self-realization. [28]. As a conclusion, in the investigation of [29] it proposed an analytical framework that allows articulating new research hypotheses related to the factors determinants of employee behavior.

\section{METHODOLOGY}

An analytical methodology it used, where the tools of surveys and brainstorming integrated. It started with the identification of all the people involved that directly related in the development of project activities. Then a participatory self-diagnosis called brainstorm carried out, where each people one related to a motivation. Subsequently a correlation made between worker satisfaction and the principle of load work vertical. Then, were measured in the team of leaders the attitudes, the motivation, the work environment and the staff skills regarding the recognition of work and the relationships between boss and employee. Last, from the brainstorm, a survey was conducted in which the results were will obtained that will allow us to plan strategies to increase labor productivity through employee motivation, applying the theory of vertical load that it is oriented to the different interest groups. This proposal closely resembles the methodological proposal of [30], which allows increase organizational learning. The above are evidenced in Figure 1.

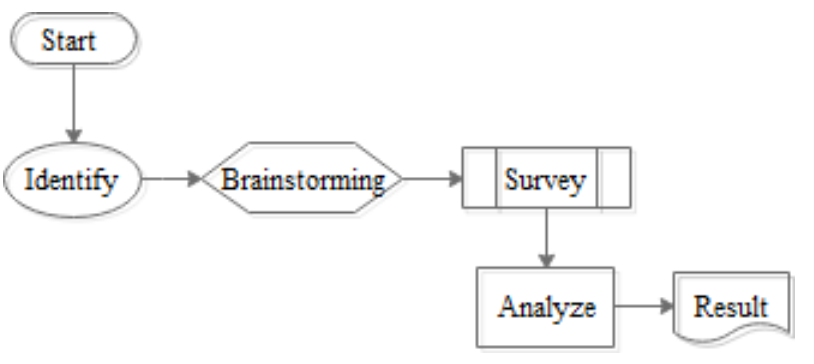

Figure 1. Applied methodology

\section{CASE STUDY}

To determine the scope of this project, consideration it will give: The result was the structuring of a project, whose first stage was the identification of the principle theory of vertical load of work, in order to know the depth on which this based. , then analyzed through the PMBOK where human resources management is oriented, which includes the processes that organize, manage and lead the project team, where the members of the project team may have different sets of skills, may be assigned full-time or part-time and can be incorporated or removed from the team as the project progresses. The key benefit of this process is that it establishes the roles and responsibilities within the project, 
the organizational charts of the project and the personnel management plan, including the timetable for the acquisition and subsequent release of personnel. [10] Within the process of human resources management, the first step was to identify the roles and responsibilities within the organization, Hefziba, Ingeniería \& Consultoría SAS, where this research was carried out, in which, it was executing several engineering projects. This company has a total 60 employees between direct and undetected. The study groups in the company classified according to a matrix of three levels according to the workload as it shown in Figure 2.

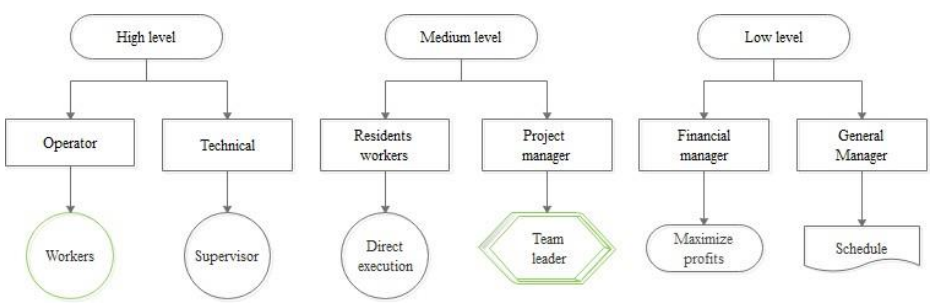

Figure 2. Work responsibilities matrix

In addition, it a few steps will have to establish to the enrichment of job, as shown in Figure 3

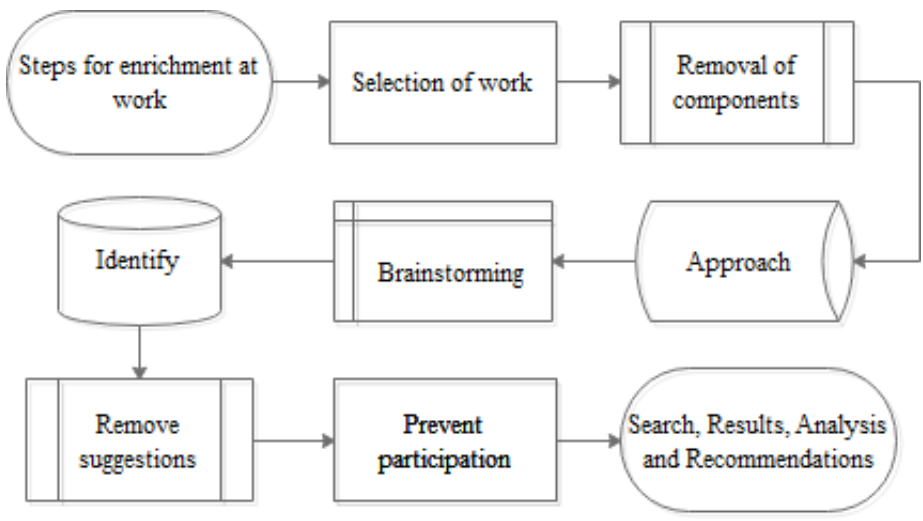

Figure 3. Sequence for Job enrichment

The active participation of professionals in the construction sector was important in the process of gathering information; what contributed to his thinking, with respect to the methods of motivation that implemented, but in general were not effective. In the development, a question format is used and brainstorming tables presented, which served as a reference for knowing the personal perspective and evaluating the indices of job satisfaction found in the construction sector. It is a survey questionnaire, conceived as perception surveys, with positive affirmations. A representative population of each project selected and the survey applied anonymously, so that all the respondents were in similar conditions, to eliminate the influences in the collection of information. Posters and bulletins also offered to provide explanatory information on the key terms of the survey to limit interpretation. Likewise, the statistical instruments for research in the projected axes were prepared. In the compilation of the information, an appropriate physical space will have selected where those selected will work to obtain the information requested in the instrument.

\section{CONCLUSION}

This model is completely replicable, where the situation presented that the staff felt a little uncomfortable for performing the activities in rest or departure times, for this reason it recommended to previous agree with the resident engineer and the project director the programming of information gathering activities outside of rest periods.

Vertical job loading principle theory it applied with the use of brainstorming and surveys, which enrich the professional knowledge of each of the project's stakeholders. In the PMBOK, it can find a set of processes that allow us to manage any type of project in a standardized way; however, it is very vital to present tools for the development of each process. In the case of this research, the theory of personal motivation used, which has to do with the management of the human resources of a project. Regarding the treatment of the stakeholders, they were identified and classified as direct and indirect, being able to purify them and work with the appropriate sample for our research, this with the purpose of achieving the least amount of alterations in the development of the degree project and its later results. The brainstorming was applied and then the personnel surveys, as main tools for the identification of the needs and shortcomings within the construction sector. Consecutively, the previous tools analyzed to establish alternative solutions and strategies that could be implementation in the projects for the improvement of productivity.

It recommended that the technical talks be the first motivating item to develop, in addition to organized by the suppliers of the work in execution, this with the intention that the employees in general, feel identified with the materials and equipment with the work every day.

The programming of extra work activities by the company is of paramount importance within a work team, as the team's understanding increases, this leads to better working relationships and therefore creating a more pleasant work environment.

This theory only applied to the industry, but in the field of construction, few studies done, it is necessary to start from the fact that the majority of companies subcontract all the works in their works, so their main function is management of projects. This implies that to apply our research work not only should have the permission of the general contractor, also those who manage the subcontracted items since their staff was to which the theory was going to apply.

Cost work to convince the resident engineers in charge of the work, skeptical in the subject, because it could take as a loss of person-hours, which translates into money.

Within the time of the investigation, it identified that some workers constantly change their companies or lose their commitment. Due to a better remuneration in other works, 
especially around the end of the work. This affects the control equipment (Supervision).

The commitment of the management and the work team to comply with each of the interventions is of vital importance, for the success of the improvement of productivity, the project managers must be committed to each of the interventions and you must create a project policy to carry out the aforementioned activities.

Work teams was it managed properly, trying to avoid the exchange of personnel as much as possible.

The project managers should commit to designing the policies necessary for the development of each of the activities that each worker performs.

The boss should do a meeting at the beginning of each workday, with should be carried out to social and technical as a motivating element, so that all workers interact each with the materials and equipment with which they carry out their work. In addition, it must carry out-group recreational activities or active breaks so that the work environment improves continuously and a better performance of the workers obtained, which would improve the labor relations between them and a high probability of increasing productivity of the company.

\section{ACKNOWLEDGEMENTS}

This paper comes from the degree project: "Evaluation of the application of the main theory of work to improve productivity in civil works projects". The authors wish to thank the engineer Claudia Ayala, HEFZIBA Engineering company, and the "Paperthone 2019" with the participation SIGME research seedbed, Lean Decisions research group belonging of the Department Productivity and Innovation University of the Coast.

\section{REFERENCES}

[1] ONU, «Economic Analysis \& Policy Division,» 2019. [En línea]. Available:

https://www.un.org/development/desa/dpad/publication/worldeconomic-situation-and-prospects-2019. [Último acceso: 2507 2019].

[2] C. G. Buron, Análisis microeconómico de la satisfacción laboral, Madrid, España.: Consejo Economico y Social. CES, 2005.

[3] R. H. Warren, Motivation and Productivity in the Construction Industry, Van Nostrand Reinhold, 1989.

[4] L. Solano Naizzir, «https://www.cuc.edu.co/investigacion/noticias/4394,» Vicerrectoría de Investigación y Desarrollo - Universidad de la Costa, $24 \quad 04$ 2019. [En línea]. Available: https://www.cuc.edu.co/investigacion/noticias/4394. acceso: 2007 2019].

[5] A. V. Moreno Charris, E. A. Chang Munoz y J. Romero de Cuba, «Satisfacción Laboral en las Pyme colombianas del sector Textil-Confección,» Revista Venezolana de Gerencia, vol. 23, n 82 , pp. 392-406, 2018.

[6] Departamento Administrativo Nacional de Estadística -DANE, «Boletín Técnico Producto Interno Bruto I Trimestre de $2020, » 2020$

[7] J. N. S. Carlos Arrieta Salas, «Motivación en el trabajo: viejas teorías, nuevos horizontes,» Actualidades en Psicología, vol. $22, \mathrm{n}^{\circ} 109$, pp. 67-89, 2008.

[8] F. Herzberg, «Una vez mas: ¿como motiva a sus empleados?,» vol. 81, 2003, pp. 67-76.

[9] A. Patiño Builes, «Tendencias tecnológicas que influyen en el aumento de la productividad empresarial.» INGE CUC, vol. 11, nº 2, pp. 84-96, 2015.

[10] P. M. Institute, Guia de los Fundamentos Para la Dirección de Proyectos PMBOOK, 2017.

[11] A. Gomez Cabrera y D. Morales Bocanegra, «Análisis de la productividad en la construcción de vivienda basada en rendimientos de mano de obra.," INGE CUC, vol. 12 , n ${ }^{\circ} 1$, pp. 21 31, 2016.

[12] J. L. MAS, «MOTIVACIÓN LABORAL Y GESTIÓN DERECURSOS HUMANOS EN LA TEORÍA DEFREDERICK HERZBERG,» revista de Investigación de la Facultad de Ciencias Administrativas, UNMSM, vol. 8, nº 15, pp. 25-36, 2005.

[13] A. N. Terlato, «MOTIVACIÓN, FACTORES INTRÍNSECOS Y PERFORMANCE. UN ESTUDIO SOBRE EMPRESAS DEL ÁREA METROPOLITANA DE BUENOS AIRES,» 2018. [En línea]. Available: https://ucema.edu.ar/publicaciones/download/documentos/628.pdf

[14] O. R. Sanchez, "Clima Organizacional en Siemens Enterprise S.A.,» $28 \quad 08$ 2018. [En línea]. Available: http://biblioteca.galileo.edu/tesario/handle/123456789/613.

[15] S. G. R. Fonseca, «Repositorio Puseca,» 2017. [En línea]. Available:

http://repositorio.pucesa.edu.ec/handle/123456789/1937. [Último acceso: 1007 2019].

[16] M. P. G. Luis Araya Castillo, «ANÁLISIS DE LAS TEORÍAS DE MOTIVACIÓN DE CONTENIDO: UNA APLICACIÓN AL MERCADO LABORAL DE CHILE DEL AÑO 2009,» PORTAL DER REVISTAS ACADEMICAS UNIVERSIDAD DE COSTA RICA, nº 142, 2009.

[17] M. L. M. -. F. F. Olaza, Mejora de la productividad de un proyecto de construcción utilizando la teoría del principio de la carga vertical de trabajo, Lima, 2011. 
[18] C. P. ESTRADA, «La motivación laboral como herramienta de gestión en las organizaciones empresariales,» 2015 .

[19] C. P. V. ALMESTAR, «Estudio de la satisfacción laboral de los trabajadores de la empresa Limones Piuranos SAC de la ciudad de Sullana, a la luz del pensamiento de Frederick Herzberg-Piura 2016,» 2017.

[20] O. H. B. PAZ, «Motivación laboral de los egresados del Programa de Administración de Empresas de la Universidad de Nariño,» Tendencias, vol. 18, $\mathrm{n}^{0}$ 1, 2017.

[21] P. F. A, «Ambiente de trabajo: Una evaluación de riesgos psicosociales y carga de trabajo mental en agentes de tránsito,» Revista de la Universidad Industrial de Santander, vol. 49, no 4 , pp. 567-576, 2017.

[22] J. N. C. BALOY, «ELABORACIÓN DE UN PLAN DE MOTIVACIÓN INSTITUCIONAL A FIN DE LOGRAR UNA FIDELIZACIÓN DE LOS COLABORADORES DE LA COMPAÑÍA EQUIVIDA S.A., DISTRITO METROPOLITANO DE QUITO 2017,» 2017.

[23] A. A. A. ESTEPHANY A. ROJAS, «Motivación laboral y compromiso organizacional en colaboradores del área logística de una empresa metálica de Lima,» 2015. [En línea]. Available: http://repositorio.usil.edu.pe/handle/123456789/1870.

[24] W. G. Diaz, «Motivación y Sastifacción en Texcol S.A.S,» BOLETIN INFORMATIVO CEI, vol. 2, nº 2, pp. 15-19, 2015.

[25] A. M. A. VELÁSQUEZ, «DISEÑO DE UN PROGRAMA DE MEJORAMIENTO DE CALIDAD DE VIDA LABORAL PARA EL DEPARTAMENTO DE VENTAS DE LA EMPRESA SANOFI ECUADOR EN EL AÑO 2016,» 2017.

[26] P. M. Lopez, «Empleados felices como principal estrategia de marketing,» Marketing mas ventas, $\mathrm{n}^{\circ} 300$, pp. 50 $57,2015$.

[27] L. M. d. R. V. Pardo, "Influencia de la satisfacción laboral en el clima organizacional en la I. E. Sara Antonieta Bullón, Lambayeque,» Lima, 2015.

[28] M. D. P. M. Helen Stephani Marin Samanez, «Motivación y satisfacción laboral del personal de una organización de salud del sector privado,» Horizonte médico, vol. 17, $\mathrm{n}^{\circ} 4$, pp. 42-52, 2017.

[29] B. FERNANDEZ MUÑIZ, J. M. MONTES PEON y C. V. VAZQUEZ ORDAS, «LEADERSHIP AND SAFETY CULTURE: STATE OF THE ART REVIEW,» DYNA, vol. 92, n 1 , pp. 39-42, 2017.

[30] T. Grubessich Fernandez, . P. Viveros Gunckel, R. Stegmaier Bravo, F. K. Janpoller Rodriguez, V. Gonzalez, P. Diaz y P. Francois, «METHODOLOGICAL PROPOSAL TO INCREASE THE UNDERSTANDING OF A COMPLEX SYSTEM TO IMPROVE THE DECISION-MAKING PROCESS,» DYNA, vol. $92, n^{\circ} 1$, p. 395, 2017. 